\title{
Risk Assessment of Mediterranean Sea Waters on Cooling System of Nuclear Power Plant
}

\author{
M. S. Tawfik, F. S. Tawfik \\ Siting \& Environmental Department, NRRA, Cairo, Egypt \\ Email: m_tawfik7@hotmail.com
}

How to cite this paper: Tawfik, M.S. and Tawfik, F.S. (2019) Risk Assessment of Mediterranean Sea Waters on Cooling System of Nuclear Power Plant. Journal of Environmental Protection, 10, 738-744. https://doi.org/10.4236/jep.2019.106044

Received: April 16, 2019

Accepted: June 14, 2019

Published: June 17, 2019

Copyright $\odot 2019$ by author(s) and Scientific Research Publishing Inc. This work is licensed under the Creative Commons Attribution International License (CC BY 4.0).

http://creativecommons.org/licenses/by/4.0/ (c) (i) Open Access

\begin{abstract}
The study evaluated the impacts such as corrosion and scale formation which may result from, using the once-through pass cooling system of a suggested nuclear power at different selected coastal regions of Alexandria coast. (Abu-Qir, Sidi Kerrir, Estern Harbour, El Max and Sidi Abd Elrhaman). The study had used The Langelier Saturation Index (LSI), which is a measure of a solution's ability to dissolve or deposit calcium carbonate, which is often used as an indicator of the corrosivity of water. Like the Langelier saturation index, the Ryznar stability index (RSI) is also used to predicate the formation of scale and also the tendency for corrosion due to the concentration of calcium carbonate in the selected water system. Both of the two indexes ((LSI) and (RSI)) had been used to evaluate the internal environmental impact which may be occurred when used once-through pass system is as a cooling method of a coastal pressurized water reactor power plant. The study results showed that the calculated LSI and RSI values for selected regions indicated that, there was a low tendency for scale formation and possibility of corrosion at these selected study areas, so using nickel copper alloys in condenser is recommended to prevent any possibility of attack of corrosion besides the using of chemical treatment method of inlet cooling water system.
\end{abstract}

\section{Keywords}

Cooling Water, Corrosion, Langelier Saturation Index

\section{Introduction}

The consideration of new nuclear power stations is split into two phases. The first phase addresses generic design matters (namely, acceptability of candidate nuclear power station designs) and the second deals with site-specific applications for permits under the Environmental Permitting Regulations 2010. Since a 
large nuclear power plant that utilizes a once-through cooling system may withdraw 800 million to 1 billion gallons of water a day, these plants are usually built next to rivers, lakes, or oceans. As the name implies, once-through cooling uses water per single time to cool and condense steam produced for electricity generation. Water produced from the condensed steam is reused in the generation process, but the water used for cooling is discharged back into the lake, river or ocean, with a temperature increase of up to 30 degrees [1]. Condenser performance is also reduced by factors such as scale on the outside (steam side) of the tubes and by slime and scale (waterside fouling) inside. These effectively insulate the tube wall [2]. The widely used Langelier Saturation Index is a useful indicator of carbonate scale formation but it is purely an equilibrium index and gives no indication of how much scale will form, or calcium carbonate will precipitate, in bringing the water to equilibrium. Scaling and corrosion are influenced by $\mathrm{pH}$, hardness, alkalinity, total dissolved solids and temperature so in theory an equilibrium condition can be maintained so that neither occurs. Other problems like the water consumption caused by the evaporation losses of the towers are also the object of controversy at several sites (3). On the other hand using once-through cooling pass may solve some of these problems such as water consumption, which Egypt government is concerned with and the rejection of thermal discharges from cooling towers [3]. Fouling risk is another environmental impact on nuclear power plant from using sea water as a cooling system, as it is classified as the deposition of marine biological organisms on certain surface called marine bio-fouling or classified as a deposition of chemical compounds such as calcium silicates and calcium carbonates, forming what is called chemical fouling; on the other hand fouling may also defined as (inorganic or organic) chemical formation [4]. The bio-fouling species attached ranged from micro-organisms (bacteria, algae) to macro-organisms (mussels, barnacles, etc.) and particulate fouling. The possibility of fouling formation in seawater medium is increasing due to the increasing of TDS, Alkalinity, salinity and Ca-hardness concentrations, leading to formation of hard insulating layer inside the condensed tubes that cause a problem in heat transfer process in the selected cooling water system [5] [6] [7].

\section{Material and Methods}

The coasts of Egypt extend over more than $3500 \mathrm{~km}$ along the Eastern Mediterranean and the Red Sea. The Mediterranean Alexandria coastal sector extends further eastward from Hammam to Abu Qir. This study aims to evaluate the environmental impacts resulted from selecting certain sites at the coastal line of Alexandria to see the acceptability of using one of these sites to be used as source of once-through pass cooling system in a pressurized water reactor (PWR) with avoiding any environmental impacts on the suggested cooling water type,field study has been done to select the suggested sites (Abou-Qir, Sidi Kirr, Al Mex, Estern Harbour and Sidi Abd Elrahman), the Abou-Qir geographic coordinates 
are $31^{\circ} 18^{\prime} 22.0^{\prime \prime} \mathrm{N} 30^{\circ} 09^{\prime} 52.0^{\prime \prime} \mathrm{E}$, while in Sidi Kirr are $31^{\circ} 05^{\prime} 21.0^{\prime \prime} \mathrm{N} 29^{\circ} 35^{\prime} 29.0^{\prime \prime} \mathrm{E}$, and $\mathrm{Al} \mathrm{Mex} \mathrm{coordinates} \mathrm{with} \mathrm{latitude} 50.498830$ and with longitude 3.611640. on the other hand, the Estern Harbour coordinates arelies between $29^{\circ} 52^{\prime} 57^{\prime \prime} \mathrm{E}$ $29^{\circ} 54^{\prime} 27^{\prime \prime} \mathrm{E}$ and $31^{\circ} 12^{\prime} 00^{\prime \prime} \mathrm{N}-31^{\circ} 12^{\prime} 54^{\prime \prime} \mathrm{N}$, and Sidi Abd Elrahaman coordinates are $30^{\circ} 57^{\prime} 59.99^{\prime \prime} \mathrm{N} 28^{\circ} 43^{\prime} 59.99^{\prime \prime E}$. The Physic-chemical analysis of sea water parameters had been measured (temperature, pH, TDS, Alkalinity, Ca-hardness, and chlorides), volumetrically and gravimetrically, by using the standard methods for water and wastewater examination [8], Samples will be taken during six months, started from $2 / 1 / 1015$ to $3 / 6 / 2015$, this period help to study the seasonal variations occurred in the selected sites, showing the effects of temperature on $\mathrm{pH}$ and other physicochemical variations. Calculation of water saturation depends on measuring of many parameters such as, total alkalinity, $\mathrm{pH}$, and calcium concentration of water. The solubility product leads to oversaturation with respect to $\mathrm{CaCO}_{3}$ that leads to precipitation of $\mathrm{CaCO}_{3}$. Such water will exhibit a tendency to be scale forming. Where the solubility product Ksp is not exceeded the water is under saturated with respect to $\mathrm{CaCO}_{3}$ and such a water, will tend to scale dissolving. The langlier sauation index (LSI) had been used for each site of the selected sites of the Alexandrian costal line, in order to evaluate the corrosion impact which may be occurred when using the once-through pass cooling water system as a cooling source of a pressurized nuclear reactor. In this study using mathematical model to control scale formation problem in suggested cooling water system. The steps of scales formation inside the condenser tubes are not found immediately after passing the supersaturated water through it. The Carbonate scale needs certain conditions to be formed, as it is not enough for the water to be super statured with $\mathrm{CaCO}_{3}$ until nucleation has occurred. The carbonic species in water is defined by five basic parameters: $\mathrm{H}_{2} \mathrm{CO}_{3}, \mathrm{HCO}_{3}^{-}$, $\mathrm{CO}_{3}^{2-}, \mathrm{OH}^{-}$and $\mathrm{H}^{+}$. Carbon dioxide plays an important role in formation of the carbonic acid (weak acid) in marine water. As $\mathrm{CO}_{2}$ enter the marine water through different pathways. The carbon dioxide dissolved into water exist not only dissolved $\mathrm{CO}_{2}$ but also as carbonic acid, $\mathrm{H}_{2} \mathrm{CO}_{3}$, which is then dissociated to $\mathrm{H}^{+}$and $\mathrm{HCO}_{3}^{-}$. The Langelier saturation index depends on the relation between saturated $\mathrm{pH}$ and measured $\mathrm{pH}$ in evaluation of water tendency in scale formation and acceptability to corrosion, which help in selection the suitable corrosion and scale formation inhibitor in order to avoid any risk in the selected condenser cooling system the [9]. The Langelier saturation index $=\mathrm{pH}-\mathrm{pH}$ where, $\mathrm{pH}$ is the measured water $\mathrm{pH}$ and $\mathrm{pHs}$ is the $\mathrm{pH}$ where the water will be saturated (at equilibrium) with respect to $\mathrm{CaCO}_{3}$. [9]. Like the Langelier saturation index, the Ryznar stability index has its basis in the concept of saturation level. The Ryznar stability index depends in its evaluation on the relation between calcium carbonate and scale formation. The Ryznar index takes the form: Ryznar stability in$\operatorname{dex}=2(\mathrm{pHs})-\mathrm{pH}[9]$. Tendency of corrosion and scale formation inside the once-through cooling water system can be calculated by using Table 1 and Table 2. 
Table 1. Interpretation of Langlier saturation index (6).

\begin{tabular}{cc}
\hline Description & Quantity \\
\hline Scale forming but non corrosive & $>2$ \\
Slightly Scale forming and Corrosive & $0.5-2$ \\
Balanced but pitting corrosive possible & $0.02-0.5$ \\
Slightly corrosive but non scale forming & $-0.5-0.02$ \\
Serious corrosion & -0.5 to -2 \\
\hline
\end{tabular}

Table 2. Interpretation of Ryznar stability index (6).

\begin{tabular}{cc}
\hline Description & Quantity \\
\hline Scale intolerable & $<4$ \\
Heavy scale & $4-5$ \\
Light scale & $5-6$ \\
Little scale or corrosion & $6-7$ \\
Corrosion significant & $7-7.5$ \\
Heavy corrosion & $7.5-9$ \\
Corrosion intolerable & $>9$ \\
\hline
\end{tabular}

\section{Results and Discussions}

Figure 1 showed that $\mathrm{Al}$ has the highest value of Langlier Saturation Index (LSI) in Estern harbor 1.78 while the lowest LSI value at Sidi Abd Elrhaman region with 1.12. On the other hand Figure 2 shows the highest value of Ryznar Stability Index (RSI) was found at Sidi Abd Elrhaman with 5.86 while the lowest RSI values found in Estern Harbor with 5.04, so depending on Langlier stability index or Ryznar stability index the selected sites for suggesting cooling system are with low tendency for scale formation [9]. Table 3 showed that the calculated LSI values for selected regions are respectively $(1.43,1.58,131,1.78$ and 1.12) and the calculated RS values are respectively $(5.04,5.24,5.48,5.04$ and 5.86) all these values indicate that there low tendency for scale formation and possibility of corrosion at these selected areas as showed at Table 1 (0.5 - 2), On the other hand Table 2 showed that the degree of scale formation which is light scale (5 6) [6]. Table 4 showed also that There is ahighly significant $t$-test +ve correlations $(\mathrm{P}<0.01)$ between Ca-hardness and LSI value which is $(+0.127)$ on the other hand Table 5 showed that there is There are highly significant $t$-test highly significance $\mathrm{t}$-test $+\mathrm{ve}$ correlations $(\mathrm{P}<0.01)$ between Ca-hardness and RSI value $(+0.333)$ as both LSI and RSI stability indexes have its basis in the concept of saturation level to quantify the relationship between calcium carbonate saturation state and scale formation. All these previous results may support the using of once-through cooling system at those selected sites (Abou-Qir, Sidi Kirr, Al Mex, Estern Harbour and Sidi Abd Elrhaman) as a source of nuclear power plant cooling water besides the using of anticorrosion chemicals in these selected sites 


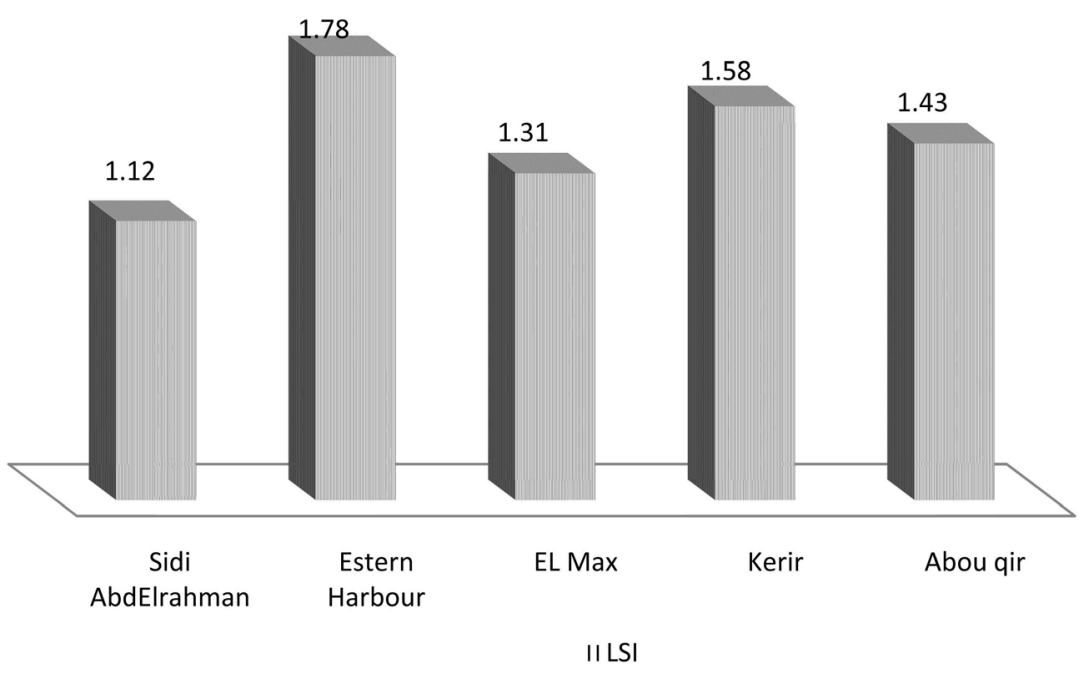

Figure 1. Determintion of Langerlier saturation index (LSI) in different sites in Alexandria costal line.

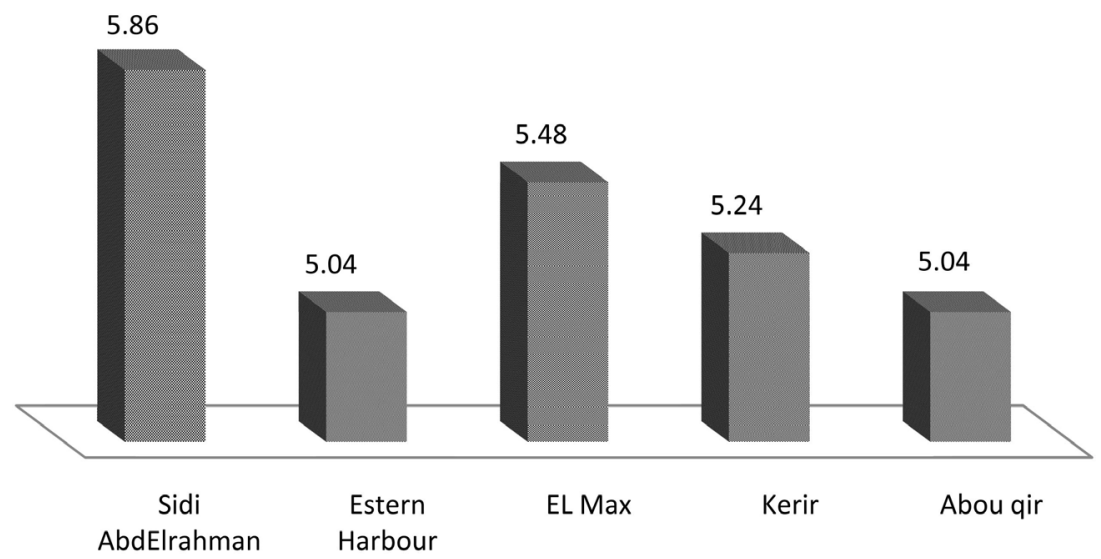

Figure 2. Determintion of Ryznar stability index (RSI) in different sites in Alexanderia coastal line.

Table 3. The mean average values of physicochemical parameters analysis of the selected areas during the period $2 / 1 / 1015$ to $3 / 6 / 2015$.

\begin{tabular}{|c|c|c|c|c|c|}
\hline Parameter & Abou-Qir & $\begin{array}{c}\text { Sidi } \\
\text { Kerir }\end{array}$ & $\begin{array}{c}\text { Estern } \\
\text { Harbour }\end{array}$ & $\begin{array}{c}\mathrm{EL} \\
\max \end{array}$ & $\begin{array}{l}\text { Sidi Abd } \\
\text { Elrhaman }\end{array}$ \\
\hline Temp ${ }^{\circ} \mathrm{C}$ & 25 & 27 & 26 & 28 & 26 \\
\hline${ }^{*} \mathrm{pH}$ & 7.9 & 8.4 & 8.1 & 8.6 & 8.1 \\
\hline TDS mg/l & 39206 & 38060 & 37750 & 37350 & 37710 \\
\hline Ca-hardness $\mathrm{mg} / \mathrm{l}$ as $\mathrm{CaCO}_{3}$ & 1110 & 1245 & 1267 & 1250 & 1222 \\
\hline Alkalinity $\mathrm{mg} / \mathrm{l}$ as $\mathrm{CaCO}_{3}$ & 140 & 160 & 165 & 156 & 140 \\
\hline Chlorides mg/l & 19,678 & 21,070 & 20,900 & 20,680 & 20,880 \\
\hline Calculated pHs & 6.47 & 6.82 & 6.79 & 6.82 & 6.98 \\
\hline Calculated LSI & 1.43 & 1.58 & 1.31 & 1.78 & 1.12 \\
\hline Calculated RSI & 5.04 & 5.24 & 5.48 & 5.04 & 5.86 \\
\hline
\end{tabular}

${ }^{*} \mathrm{pH}$ is not a average value. 
Table 4. Correlation coefficient $(\mathrm{r}+)$ between LSI and Ca-hardness values of the selected areas during the period $2 / 1 / 1015$ to $3 / 6 / 2015$.

\begin{tabular}{ccccccc}
\hline Parameter & Abou-Qir & $\begin{array}{c}\text { Sidi } \\
\text { Kerir }\end{array}$ & $\begin{array}{c}\text { Estern } \\
\text { Harbour }\end{array}$ & $\begin{array}{c}\text { EL } \\
\max \end{array}$ & $\begin{array}{r}\text { Sidi Abd } \\
\text { Elrhaman }\end{array}$ & Correlation \\
\hline Calculated LSI & 1.43 & 1.58 & 1.31 & 1.78 & 1.12 & +0.127 \\
Ca-hardness mg/l as $\mathrm{CaCO}_{3}$ & 1110 & 1245 & 1267 & 1250 & 1222 & \\
\hline
\end{tabular}

T-test for significance of $\mathrm{r}+, \mathrm{P}<0.001$.

Table 5. Correlation coefficient $(\mathrm{r}+$ ) between RSI and Ca-hardness values of the selected areas during the period $2 / 1 / 1015$ to $3 / 6 / 2015$.

\begin{tabular}{ccccccc}
\hline Parameter & Abou-Qir & $\begin{array}{c}\text { Sidi } \\
\text { Kerir }\end{array}$ & $\begin{array}{c}\text { Estern } \\
\text { Harbour }\end{array}$ & $\begin{array}{c}\text { EL } \\
\text { max }\end{array}$ & $\begin{array}{c}\text { Sidi Abd } \\
\text { Elrhaman }\end{array}$ & Correlation \\
\hline Calculated LSI & 1.43 & 1.58 & 1.31 & 1.78 & 1.12 & +0.333 \\
Ca-hardness mg/l as $\mathrm{CaCO}_{3}$ & 1110 & 1245 & 1267 & 1250 & 1222 & \\
\hline
\end{tabular}

T-test for significance of $\mathrm{r}+\mathrm{P}<0.001$.

of cooling water with using nickel copper alloys in condenser material to prevent any attack of corrosion and at selected sites. On the other hand there are another protection methods in case of using once-through cooling system in once-through cooling power plants, such as Abou-Qir and Sidi Kerir steam power stations, like screens and debris filters with different diameters to prevent any debris and fouling accumulation beside the low degree of scale formation which may lead to the decreasing the efficiency of cooling that leads to negative impacts to nuclear power plants operation

\section{Conclusions}

- Using the once-through pass cooling system is a suitable cooling system of a suggested nuclear power for different selected coastal regions, of Alexandria coast (Abu-Qir, Sidi Kerrir, Estern Harbour, El Max and Sidi Abd Elrhaman) due to the decreases of its possibility of exposure to corrosion and scale formation impacts.

- The importance of using different corrosion and scale formation indexes (Langelier saturation index and Ryznar stability index) when suggesting a new cooling system of nuclear power plant especially when it is located at coastal area to avoid any environmental impacts may occur on the suggested cooling system.

- Using nickel-copper alloys in condenser prevents any possibility of attack of corrosion besides using pretreatment methods of cooling water (screens and debris filter) case of using once-through cooling system such as other coastal conventional steam power of Alexandria.

\section{Conflicts of Interest}

The authors declare no conflicts of interest regarding the publication of this paper. 


\section{References}

[1] Union of Concerned Scientists (2011) Nuclear Power and Water. Fact Sheet, UCS, Washington DC.

[2] Turnpenny, A.W.H., Coughlan, J., Ng, B., Crews, P., Bamber, R.N. and Rowles, P. (2010) Cooling Water Operation for New Generation of Nuclear Power Stations in the UK. Water Side Drive, Environment Agency, Rio House.

[3] Bogh, P. and Bhargava, N. (1974) Combined Dr Y/Wet-Cooling Towers: Their Environmental Promise and Their Problems. Report, IAEA-SH-187/44, International Atomic Energy Authority, 45-62.

[4] Hawkes, J.M. (2004) The Simulation and Study of Conditions Leading to Axial Offset Anomaly in Pressurized Water Reactors. Georgia Institute of Technology Master of Science Thesis, School of Mechanical Engineering, Georgia Institute of Technology, Atlanta, GA.

[5] Bott, T.R. (1995) Heat Exchanger Cleaning. Fouling of Heat Exchangers (Chemical Engineering Monographs), 26, 357-407. https://doi.org/10.1016/B978-044482186-7/50017-8

[6] Abdosalehi, E., Banegad, H. and Zare Abyaneh, H. (2009) Conceptual Consideration Concerning water quality of Gezel-Ozan River in Iran. Thirtheenth International Water Technology Conference (IWTC), Hurghada, 12-15 March 209, 333-342.

[7] El-Saharty, A.A. (2013) Radioactive Survey of Coastal Water and Sediments across Alexandria and Rashid Coasts. The Egyptian Journal of Aquatic Research, 39, 21-30. https://doi.org/10.1016/j.ejar.2013.02.001

[8] APHA, AWWA and WPCF (1995) Standard Methods for Examination of Water and Wastewater. Washington DC.

[9] Water Cycle (1999) Predictive Modeling of Scale, Corrosion, \& Inhibitor Dosages French Creek for Cooling Water. Copyright French Creek Software, Inc., Kimberton 